\title{
Studi persepsi visual perempuan pengendara terhadap desain sepeda motor skuter matik di Indonesia
}

\author{
Linda Lukita, ${ }^{1 *}$ Achmad Syarief, ${ }^{2}$ Slamet Riyadi, ${ }^{3}$ Andar Bagus Sriwarno ${ }^{4}$ \\ ${ }^{1}$ Program Studi Magister Desain, Institut Teknologi Bandung, Bandung, Indonesia dan PT Astra Honda Motor, Jakarta, Indonesia \\ 2,3,4 Kelompok Keahlian Manusia dan Desain Produk Industri, Institut Teknologi Bandung, Bandung,Indonesia
}

\begin{abstract}
This study is an evaluation of perception and identification of attractive scooter design by female motorcycle riders. Survey with questionaire using Likert scale was conducted on 150 female scooter riders who provided assesment of six scooter design representing design of scooter in Indonesia. Descriptive analysis results show that scooter designs in Indonesia have perception: quality, comfortable to use, can be used by all family members, fun to use, relax and easy, and give confidence, which included in physio, socio, and psycho-pleasure also only reached the visceral and behavioral stage.Female riders' perception is inline with the female gender characteristics, communal and have high empathy or emotional skill. Attractive scooter design for female riders has ideo-pleasure related perception and is determined from the details of the product design. From the factor analysis, it is described the pleasurability factors has different perception for each design. Conclusion of this study is beside size, type, and design characters, total shape as well as the details of the shape from the scooter design are the things that will affect the perception of the female rider and may provide a different perception of pleasurability evaluation from the female riders.
\end{abstract}

Key words: visual perception, shape, scooter, gender difference, female rider, pleasurability

\begin{abstract}
Abstrak
Studi ini merupakan evaluasi persepsi dan identifikasi bentuk skuter matik yang menarik oleh perempuan pengendara. Survei dengan menggunakan kuesioner dengan skala bertingkat Likert dilakukan terhadap 150 orang perempuan pengendara skuter matik yang memberikan penilaian terhadap enam bentuk skuter matik yang mewakili desain skuter matik di Indonesia. Hasil analisis deskriptif menunjukkan desain skuter matik di Indonesia memiliki persepsi berkualitas, nyaman untuk digunakan, dapat digunakan oleh seluruh anggota keluarga, menyenangkan untuk digunakan, rileks dan santai, dan memberikan rasa percaya diri saat digunakan yang termasuk dalam physio, socio dan psycho-pleasure serta baru mencapai tahap visceral dan behavioral. Persepsi sesuai dengan karakteristik gender perempuan yaitu komunal dan memiliki empati atau emosional yang tinggi. Model skuter matik yang dianggap menarik oleh perempuan pengendara memiliki persepsi yang masuk dalam ideopleasure dan ditentukan dengan detail bentuk dari desain skuter matik. Hasil analisis faktor menunjukkan pembentukan faktor persepsi yang berbeda antar model skuter matik. Kesimpulan dari studi ini adalah selain ukuran, tipe, dan karakter bentuk, desain baik secara keseluruhan maupun detail serta karakteristik gender mempengaruhi perbedaan persepsi visual yang dimiliki oleh perempuan pengendara terhadap bentuk desain skuter matik.
\end{abstract}

Kata kunci: persepsi visual, bentuk, skuter matik, perbedaan gender, perempuan pengendara, pleasurability

\section{Pendahuluan}

Sepeda motor adalah merupakan jenis kendaraan bermotor dengan jumlah terbanyak di Indonesia Pada tahun 2017 jumlah sepeda motor yang beredar di Indonesia mencapai 112 juta unit atau $81.6 \%$ dari total jumlah kendaraan bermotor di Indonesia (Badan Pusat Statistik, 2018a). Berdasarkan data penjualan sepeda motor pada tahun 2018, skuter matik merupakan tipe sepeda motor dengan kontribusi penjualan terbanyak sebesar $84.6 \%$ dari total penjualan atau sebanyak 6,4 juta unit (Asosiasi Industri Sepeda Motor Indonesia, 2019). Beberapa alasan skuter matik menjadi pilihan adalah selain karena kemudahan dan kenyamanan dalam

\footnotetext{
* Corresponding author Tel : +62-818-634-380 ; fax +62-21-651-8886 ; e-mail : lukita.linda@astra-honda.com.
} 
berkendara, skuter matik merupakan tipe sepeda motor yang banyak digunakan dibandingkan tipe sepeda motor lainnya.

Di Indonesia, jumlah perempuan pengendara sepeda motor selama 10 tahun terakhir terus mengalami peningkatan, dimana pada tahun 2008 tercatat sebesar 19\% dan kemudian pada tahun 2019 tercatat sebesar $30.8 \%$ pengendara sepeda motor adalah perempuan atau meningkat sebesar $11.8 \%$ selama periode tersebut (PT Astra Honda Motor, 2018). Jumlah penduduk perempuan di Indonesia sendiri pada tahun 2018 adalah sebesar $49.76 \%$ atau sebanyak 131,5 juta dan diproyeksikan pada tahun 2032 jumlah penduduk perempuan akan melampaui jumlah penduduk laki-laki (Badan Pusat Statistik, 2018b).

Segmentasi pasar berdasarkan secara gender sendiri juga merupakan salah satu variabel yang penting (Popcorn \& Marigold, 2008). Dalam desain produk, pemahaman terkait perbedaan gender dalam proses fitur produk adalah penting bagi desainer yang memungkinkan mereka untuk berkomunikasi dengan segmen market yang berbeda dan menghasilkan produk yang efektif untuk setiap segmen (Massar \& Buunk, 2013). Terkait dengan emotional design, perbedaan gender dapat menjadi faktor utama yang harus dipertimbangkan (Szalma, 2009).

Desain skuter matik di Indonesia yang dikembangkan oleh para desainer dari pemilik merek tidak hanya mempertimbangkan karakteristik umum pengendara Indonesia namun juga mempertimbangkan karakteristik regional, secara spesifik belum banyak menggunakan orientasi perempuan pengendara. Sama halnya pada gambaran skuter matik dalam materi komunikasi yang menyesuaikan dengan ukuran, tipe bentuk serta karakter bentuk skuter matik juga belum banyak menggunakan orientasi perempuan sebagai pengendara. Beberapa model skuter matik mencoba menggunakan warna dan grafis produk tertentu selain menampilkan perempuan sebagai pengendara dalam materi komunikasinya untuk menarik minat perempuan terhadap sebuah desain skuter matik. Dengan meningkatnya jumlah perempuan pengendara seiring dengan semakin meningkatnya jumlah penduduk perempuan, maka diperlukan pemahaman akan desain skuter matik yang sesuai dan menarik bagi perempuan pengendara.

Menurut Jordan (2000), terdapat enam elemen desain produk, yaitu: warna, bentuk, grafis produk, material, suara, dan desain interaksi. Bentuk sebuah produk sebagai salah satu bagian dari elemen bentuk yang berkaitan dengan penampilan produk dapat mempengaruhi emosi penggunanya. Tampilan visual bentuk merupakan elemen desain yang paling mudah untuk menarik perhatian (Norman, 2004). Salah satu elemen desain produk terpenting adalah produk, tidak terkecual pada desain sepeda motor. Tampilan produk yang menarik dapat menghasilkan perasaan emosional positif yang mempengaruhi pengalaman aktual dengan persepsi (Norman, 2004). Persepsi terhadap produk dapat berbeda antara laki-laki dan perempuan, dengan mempertimbangkan perbedaan gender yang tidak terbatas pada perbedaan mendasar secara fisiologis namun juga pada level kognitif (Vanston \& Strother, 2017). Perbedaan gender juga mempengaruhi persepsi terhadap desain sepeda motor seperti persepsi terkait ukuran, performa, serta preferensi bentuk (Yang \& Chen, 2014). Dalam psikologi konsumen, dengan memahami bagaimana masing-masing gender memiliki perbedaan dalam gaya proses kognitif, melakukan respon afektif, dan memberikan reaksi terhadap sebuah produk menjadi aspek yang penting dalam mengantisipasi terhadap pilihan produk dan preferensi produk mereka (Meyers-Levy \& Loken, 2015).

Berdasarkan penelitian terhadap desain skuter matik sebelumnya, perempuan memperhatikan bobot yang ringan, ukuran yang kecil, kemudahan penggunaan, serta kemampuan penyimpanan untuk pemilihan desain skuter matik yang menarik (Yang \& Chen, 2014) yang termasuk dalam bagian kebutuhan fungsional dan usabilitas. Untuk mendapatkan gambaran desain skuter matik yang sesuai dan menarik bagi perempuan pengendara di Indonesia, maka perlu dilakukan evaluasi persepsi perempuan pengendara terhadap desain skuter matik di Indonesia berdasarkan kebutuhan dari perempuan pengendara. Menurut Jordan (2000), kebutuhan manusia terdiri dari tiga tingkatan, yaitu: fungsionalitas, usabilitas dan pleasurability. Pemahaman terhadap pleasurability akan memberikan pemahaman yang menyeluruh dan holistik, termasuk pemahaman terhadap kebutuhan perempuan pengendara berdasarkan pleasurability. Selain itu untuk memahami dimensi persepsi perempuan pengendara terhadap desain skuter matik di Indonesia diperlukan identifikasi terhadap faktor-faktor pembentuk desain skuter matik yang menarik bagi mereka.

Pemahaman akan karakteristik dan persepsi dari perempuan pengendara terhadap desain skuter matik di Indonesia berdasarkan faktor pleasurability diharapkan dapat memberikan gambaran kebutuhan secara menyeluruh dan juga memberikan gambaran desain skuter matik yang menarik bagi perempuan pengendara yang dapat digunakan sebagai acuan bagi para desainer produk maupun pelaku bisnis industri sepeda motor dalam pengembangan dan penentuan 
desain skuter matik yang mengapresiasi perbedaan gender sehingga dapat meningkatkan preferensi perempuan pengendara di Indonesia, selain itu sebagai wawasan dalam penyusunan gambaran produk skuter matik dalam materi komunikasi yang sesuai untuk perempuan pengendara bagi para pelaku bisnis sepeda motor di Indonesia, serta gambaran dalam upaya lebih memahami karakteristik perempuan pengendara Indonesia yang dapat digunakan dalam pengembangan industri dan bisnis sepeda motor di Indonesia.

\section{Bahan dan metode}

Berdasarkan Asosiasi Industri Sepeda Motor Indonesia, skuter matik di Indonesia dibedakan menjadi dua segmen yang dibagi berdasarkan kapasitas mesin yaitu skuter matik dengan kapasitas mesin dibawah $125 \mathrm{cc}$ dan skuter matik dengan kapasitas diatas $125 \mathrm{cc}$. Skuter matik dengan kapasitas mesin dibawah $125 \mathrm{cc}$ menguasai penjualan dengan kontribusi sebesar 64,86\% (Asosiasi Industri Sepeda Motor Indonesia, 2019). Terkait dengan bentuk, dari keseluruhan model skuter matik di Indonesia dapat dikelompokkan berdasarkan kategori ukuran, tipe bentuk, dan karakter bentuk. Berdasarkan ukuran, skuter matik dapat dikelompokkan berdasarkan kategori ukuran kecil, menengah, dan besar. Sedangkan berdasarkan tipe bentuk, dapat dikelompokkan menjadi tipe flat deck dan center tunnel. Kemudian berdasarkan karakter bentuk dapat dikelompokkan menjadi empat karakter bentuk, yaitu: curved body shape-soft body lines, plain body shapeflowing body lines, tapered body shape-sharp body lines, dan muscular body shape-firm body lines.

Kajian tentang desain sepeda motor skuter matik ini melibatkan variabel gender perempuan. Untuk itu, perbedaan gender dan karakteristik perempuan perlu dipahami sebagai bahan kajian. Menurut MeyersLevy dan Loken (2015) terdapat empat pendekatan teoritis yang memberikan penjelasan menyeluruh terjadinya perbedaan gender, yaitu: sosio-kultur, evolusioner, pendekatan ilmiah dari hormon dan fungsi otak, dan hipotesis selektif (selectivity hypothesis). Secara keseluruhan temuan yang menonjol terkait perbedaan gender perempuan yaitu: komunal, lebih memiliki orientasi pada orang lain, menempatkan pemuasan kebutuhan orang lain terlebih dahulu sebelum memenuhi kepuasan pribadi (Silverman, 2003), lebih sensitif terhadap petunjuk dari lingkungan sehingga membuat perempuan menyesuaikan perilaku mereka dengan konteks lingkungan yang sesuai (Wood \& Eagly, 2012); lebih responsif terhadap stimulus negatif dari lingkungan (Hampson, van Anders, \& Mullin, 2006) sehingga lebih bersifat waspada dan berfokus untuk menghindar; memiliki kecerdasan emosional, dan otak perempuan didominasi dengan kemampuan untuk empati (Baron-Cohen, 2003); memproses informasi atau data secara komprehensif, sehingga perempuan memiliki kemampuan untuk mendeteksi, menguraikan lebih luas, dan menggunakan seluruh informasi baik yang berhubungan langsung maupun tidak ketika melakukan penilaian, serta pada saat mengambil keputusan perempuan mempertimbangkan seluruh aspek internal baik yang bersifat personal maupun kondisi sosial serta seluruh atribut produk yang tersedia (Meyers-Levy, 1989).

Pada proses pemilihan produk, perempuan memiliki gaya mencari variasi dan merupakan bagian dari rekreasi dengan menikmati proses pemilihan produk dengan pilihan yang beragam dan fokus pada detail dari masing-masing produk (Mitchell \& Walsh, 2004). Perempuan juga lebih menghabiskan waktu untuk memperhatikan detail dari desain produk $(\mathrm{Qu} \&$ Guo, 2019), fitur produk (Darley \& Smith, 1995), serta aspek yang berhubungan dengan "orang" (Lippa, 2010). Terkait dengan sepeda motor, perempuan memilih model dengan bobot yang ringan, ukuran kecil, kemudahan penggunaan, memiliki fungsi penyimpanan barang yang besar, dan dapat digunakan untuk menjemput anak dan berbelanja (Yang \& Chen, 2014). Perempuan lebih banyak menggunakan skuter matik untuk keperluan bersama, dan selain desain kenyamanan berkendara dan performa merupakan faktor yang seimbang dalam penentuan pembelian skuter matik (PT Astra Honda Motor, 2018).

\section{Pleasurability dan tingkatan proses interaksi}

Pemahaman secara holistik terhadap manusia dan kebutuhannya akan memberikan pandangan menyeluruh dalam desain produk. Berdasarkan faktor manusia, Jordan (2000) menetapkan hirarki kebutuhan terkait dengan produk menjadi tiga tingkatan, yaitu fungsionalitas, usabilitas, dan pleasurability. Dengan memahami tingkat pleasurability dari sebuah produk maka dapat memahami hubungan antara seseorang dengan sebuah produk yang tidak terbatas pada aspek fungsionalitas dan usabilitas dari karakteristik kognitif dan fisik dari seseorang namun juga memahami aspek emosionalnya. Pleasurability sendiri terdiri dari empat kelompok, yaitu physio-pleasure yang didapatkan dari indra atau organ sensor dan berkaitan erat dengan aspek fisik tubuh manusia, socio-pleasure yang berkaitan erat dengan hubungan atau interaksi dengan lingkungan atau orang lain disekitar, psycho- 
pleasure yang berkaitan erat dengan kemudahan pengoperasian dan manfaat psikologis yang didapatkan dari produk, dan ideo-pleasure yang berkaitan dengan nilai-nilai yang dimiliki yang menentukan bagaimana bertindak dan menilai dirinya sendiri. Agar dapat didapatkan pemahaman yang menyeluruh, maka diperlukan pemahaman berdasarkan faktor pleasurability (Jordan, 2000).

Estetika produk seperti bentuk dan warna dapat mempengaruhi respon emosional terhadap produk (Macdonald, 1999). Produk yang menarik dianggap berfungsi lebih baik, daya tarik dari produk menghasilkan emosi yang positif yang membuat proses menggunakan produk menjadi seakan-akan lebih menyenangkan dan mengabaikan kesulitan yang mungkin ada.

Norman (2004) juga menyatakan ada tiga tingkatan interaksi antara produk dengan penggunanya, yaitu visceral yang berkaitan dengan tampilan produk, behavioral yang berkaitan dengan kenikmatan dan efektifitas dalam penggunaan, serta reflective yang dipengaruhi latar belakang pengalaman. Physiopleasure mengkombinasikan aspek yang didapat pada proses visceral dan sebagian dari behavioral. Sociopleasure mengkombinasikan proses behavioral dan reflective, sedangkan psycho-pleasure berhubungan dengan tingkat behavioral. Ideo-pleasure merupakan refleksi dari pengalaman, sehingga bersifat reflective.

Penelitian ini dilakukan di kota Bandung pada tanggal 11, 12, dan 23 November 2019. Dasar pemilihan kota Bandung adalah karena selain merupakan ibukota provinsi Jawa Barat yang memiliki kontribusi penjualan sepeda motor terbesar (Asosiasi Industri Sepeda Motor Indonesia, 2019), kota Bandung juga merupakan salah satu kota pendidikan, seni dan teknologi yang sering menjadi kota acuan trend desain sepeda motor Indonesia.

Studi persepsi visual perempuan pengendara terhadap desain sepeda motor skuter matik di Indonesia dilakukan melalui penelitian kuantitatif dengan pendekatan statistik inferensial. Evaluasi dilakukan dengan menggunakan kuesioner melalui indepth interview dan dibantu dengan gambar obyek penelitian dalam proses evaluasi persepsi terhadap desain skuter matik yang menjadi stimuli. Responden diminta untuk memberikan penilaian berdasarkan skala bertingkat terhadap masing-masing faktor pleasurability setelah mengamati kartu gambar yang telah disediakan.

Terdapat dua kuesioner yang digunakan dalam penelitian ini, pertama, kuesioner pre-interview yang digunakan untuk mendapatkan data profil dan karakteristik responden selain digunakan juga untuk mengkonfirmasi responden sesuai dengan kriteria, dan kuesioner in-depth interview yang merupakan kuesioner utama. Terkait dengan penilaian responden terhadap desain skuter matik yang menjadi stimuli, digunakan sejumlah enam belas faktor penilaian yang disusun berdasarkan alasan pembelian sepeda motor skuter matik (PT Astra Honda Motor, 2018) dengan komposisi sejumlah empat faktor untuk masingmasing pleasurability. Enam belas faktor yang digunakan untuk mengevaluasi persepsi, sebagai berikut: berkualitas, nyaman untuk digunakan, bobotnya ringan, ramping dan gesit, dapat digunakan oleh seluruh anggota keluarga, terkait status atau lingkungan sosial tertentu, dapat membuat pemilik/pengendara terlihat berbeda dan menonjol, dapat membuat pemilik/pengendara diterima dalam lingkungan pergaulan sebaya, menyenangkan untuk digunakan, rileks dan santai untuk digunakan, memberikan rasa percaya diri saat digunakan, memberikan perasaan bebas dan mudah saat digunakan, terlihat feminin, menunjukkan kemandirian, ramah lingkungan, dan terlihat ekonomis dan murah.

Evaluasi terhadap persepsi desain skuter matik menggunakan skala bertingkat tipe Likert, dengan skala numerik ordinal yang menggunakan angka 1 sampai dengan 10, dimana angka 1 menunjukkan "sangat tidak setuju" dan angka 10 menunjukkan "sangat setuju". Skor penilaian diintrepretasi dengan bantuan pembagian rentang skala bertingkat menjadi empat kategori sebagai berikut: skor $1.00-3.25=$ "sangat tidak setuju/STS", skor 3.25 - 5.50 = "tidak setuju/TS", skor $5.50-7.75=$ "setuju/S", skor $7.75-$ $10.00=$ "sangat setuju/SS".

Dalam proses evaluasi persepsi visual, penelitian menggunakan kartu stimulus atau kartu gambar yang menunjukkan gambar masing-masing obyek penelitian. Keseluruhan kartu stimulus memiliki gambar yang tidak berwarna dan menggunakan warna monokromatik. Masing-masing kartu gambar juga memiliki gambar stimuli dengan sudut proyeksi dimetri yang hampir mirip. Keduanya diharapkan mampu menjaga reliabilitas dan relevansi data yang didapatkan.

Stimuli dari penelitian ini adalah enam model sepeda motor tipe skuter matik yang dipilih berdasarkan jumlah penjualan unit terbanyak menurut data penjualan semester I 2018 (Asosiasi Industri Sepeda Motor Indonesia, 2019) pada masing-masing segmen, yaitu segmen diatas $125 \mathrm{cc}$ dan segmen dibawah $125 \mathrm{cc}$, dari dua brand sepeda motor yang ada di Indonesia, yaitu Honda BeAT, Honda Scoopy, Honda Vario 125, Yamaha NMax, Yamaha Mio, dan Honda PCX, yang mewakili gambaran desain skuter matik di Indonesia, terlihat pada Tabel 1. 
Tabel 1. Stimuli obyek penelitian

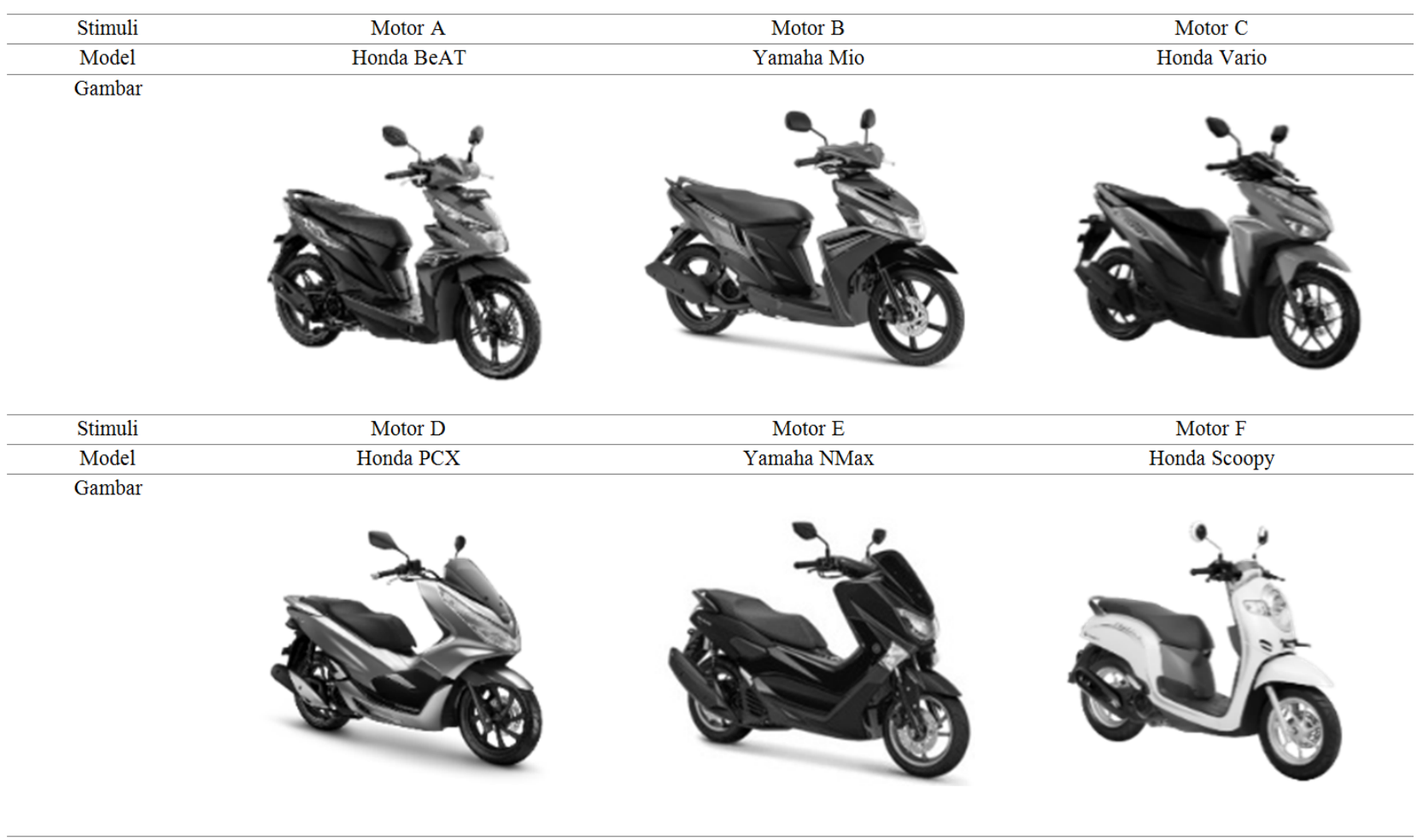

Sejumlah 150 perempuan pengendara dari masingmasing model skuter matik yang menjadi stimuli penelitian, dengan rentang usia 17 - 35 tahun (ratarata usia $=23.6$ tahun) yang berdomisili di Bandung merupakan responden dari penelitian ini. Komposisi jumlah perempuan pengendara yang menjadi responden untuk setiap model skuter matik dibuat rata sejumlah 25 responden masing-masing, dengan tujuan untuk menghilangkan kemungkinan kecenderungan responden terhadap salah satu tipe skuter matik yang merupakan kendaraan sehari-hari dari responden tersebut.

Selain itu untuk menjaga reliabilitas penelitian dan relevansi data, responden juga sudah mengetahui dan sudah pernah melihat seluruh skuter matik yang menjadi obyek penelitian, merupakan pengguna utama atau pemiliki dari skuter matik yang menjadi kriteria penelitian, menggunakan skuter matik tersebut untuk keperluan pribadi dan bukan merupakan ojek online ataupun motor dinas milik perusahaan, merupakan pengambil keputusan sendiri dalam pembelian skuter matik tersebut ataupun bersama dengan keluarga, dalam jangka waktu 1 (satu) tahun, responden tidak pernah mengikuti penelitian serupa ataupun penelitian lainnya yang terkait dengan sepeda motor, telah mengendarai skuter matiknya dengan jarak tempuh mencapai minimal $200 \mathrm{~km}$, jangka waktu pembelian skuter matik adalah maksimal 3 (tiga) tahun, memiliki kemampuan komunikasi yang baik, merek bukan merupakan alasan utama responden dalam melakukan pembelian skuter matik mereka.

Analisis deskriptif dilakukan terhadap data kuantitatif persepsi perempuan pengendara terhadap enam bentuk desain skuter matik digunakan untuk mendapatkan hasil evaluasi persepsi desain skuter matik di Indonesia oleh perempuan pengendara berdasarkan faktor-faktor pleasurability dan untuk mengidentifikasi bentuk skuter matik yang menarik bagi perempuan pengendara.

Analisis faktor dilakukan pada data kuantitatif persepsi perempuan pengendara terhadap enam bentuk desain skuter matik dengan bantuan aplikasi SPSS (Statistical Package for the Social Science) versi IBM SPSS 23 untuk menentukan faktor yang dominan pada masing-masing desain skuter matik obyek penelitian. Metode analisis faktor menggunakan metode Principal Component Analysis dan rotasi menggunakan metode Varimax dengan Kaiser Normalization. 
Tabel 2. Pembentukan faktor pleasurability

\begin{tabular}{|c|c|c|c|c|c|c|c|c|c|c|c|c|}
\hline \multirow[t]{2}{*}{ Pleasure } & \multirow[t]{2}{*}{ Aspek } & \multicolumn{6}{|c|}{ Motor } & \multirow[t]{2}{*}{ Mean } & \multicolumn{4}{|c|}{ Kategori Skala } \\
\hline & & A & B & $\mathrm{C}$ & D & $\mathbf{E}$ & $\mathbf{F}$ & & STS & TS & $\mathbf{S}$ & SS \\
\hline \multirow[t]{4}{*}{ Plyysio } & Berkualitas & 7.55 & 7.48 & 8.70 & 9.19 & 9.15 & 8.34 & 8.40 & 0 & 0 & 2 & 4 \\
\hline & Nyaman & 7.99 & 7.39 & 7.88 & 8.31 & 8.31 & 8.48 & 8.06 & 0 & 0 & 1 & 5 \\
\hline & Ringan & 8.75 & 7.08 & 5.86 & 5.21 & 5.31 & 8.34 & 6.76 & 0 & 2 & 2 & 2 \\
\hline & Ramping Gesit & 8.78 & 7.27 & 6.07 & 5.09 & 5.35 & 7.99 & 6.76 & 0 & 2 & 2 & 2 \\
\hline \multirow[t]{4}{*}{ Socio } & Digunakan Keluarga & 8.48 & 7.91 & 7.92 & 7.15 & 7.24 & 8.46 & 7.86 & 0 & 0 & 2 & 4 \\
\hline & Terkait Status & 6.34 & 6.37 & 6.91 & 7.97 & 7.73 & 6.84 & 7.03 & 0 & 0 & 5 & 1 \\
\hline & Berbeda/Menonjol & 5.87 & 5.90 & 7.24 & 8.55 & 8.45 & 7.27 & 7.21 & 0 & 0 & 4 & 2 \\
\hline & Diterima Lingkungan & 6.68 & 6.66 & 7.37 & 8.01 & 7.85 & 7.39 & 7.33 & 0 & 0 & 4 & 2 \\
\hline \multirow[t]{4}{*}{ Psycho } & Menyenangkan & 7.98 & 7.33 & 7.81 & 8.08 & 8.20 & 8.23 & 7.94 & 0 & 0 & 1 & 5 \\
\hline & Rileks dan Santai & 8.23 & 7.51 & 7.65 & 8.07 & 7.95 & 8.40 & 7.97 & 0 & 0 & 2 & 4 \\
\hline & Percaya Diri & 7.56 & 7.02 & 7.85 & 8.68 & 8.49 & 7.97 & 7.93 & 0 & 0 & 2 & 4 \\
\hline & Bebas dan Mudah & 8.22 & 7.37 & 7.52 & 7.65 & 7.77 & 8.25 & 7.80 & 0 & 0 & 4 & 3 \\
\hline \multirow[t]{4}{*}{ Ideo } & Feminin & 7.64 & 6.13 & 5.90 & 5.75 & 5.26 & 8.85 & 6.59 & 0 & 1 & 4 & 1 \\
\hline & Kemandirian & 7.30 & 6.90 & 7.47 & 7.71 & 7.75 & 7.71 & 7.47 & 0 & 0 & 5 & 1 \\
\hline & Ramah Lingkungan & 7.74 & 7.25 & 7.56 & 7.46 & 7.53 & 8.06 & 7.60 & 0 & 0 & 5 & 1 \\
\hline & Ekonomis dan Murah & 8.24 & 7.49 & 6.35 & 4.51 & 5.26 & 7.63 & 6.58 & 0 & 2 & 3 & 1 \\
\hline \multirow[t]{4}{*}{ Skala } & STS & 0 & 0 & 0 & 0 & 0 & 0 & & & & & \\
\hline & TS & 0 & 0 & 0 & 3 & 4 & 0 & & & & & \\
\hline & $\mathbf{S}$ & 8 & 15 & 11 & 5 & 3 & 5 & & & & & \\
\hline & SS & 8 & 1 & 5 & 8 & 9 & 11 & & & & & \\
\hline
\end{tabular}

Dari hasil analisis faktor tersebut didapatkan pengelompokan faktor-faktor yang terbentuk untuk masing-masing desain. Dari pengelompokan tersebut dilakukan pemetaan persepsi perempuan pengendara terhadap masing-masing desain skuter matik di Indonesia.

\section{Hasil dan Pembahasan}

Terhadap desain skuter matik, perempuan pengendara memiliki persepsi: terlihat berkualitas, nyaman untuk digunakan, dapat digunakan oleh seluruh anggota keluarga, menyenangkan untuk digunakan, rileks dan santai, dan memberikan rasa percaya diri saat digunakan, seperti terlihat pada Tabel 2. Dari empat tipe pleasurability, persepsi perempuan pengendara hanya meliputi tiga tipe, yaitu physio-pleasure, socio-pleasure, dan psycho-pleasure dengan aspek socio-pleasure dan ideo-pleasure yang belum terwakili secara signifikan dari desain skuter matik yang ada di Indonesia. Berdasarkan tingkat interaksi produk dengan pengguna (Norman, 2004), hal itu masih dalam tahap visceral dan behavioral dan belum mencapai tahap reflective yang dipengaruhi oleh socio-pleasure dan ideo-pleasure. Untuk meningkatkan interaksi dan memperkuat hubungan antara skuter matik dengan penggunanya serta untuk dapat meningkatkan preferensi perempuan pengendara terhadap desain skuter matik, maka tingkat interaksi perlu ditingkatkan sebagaimana yang dikatakan oleh Norman, bahwa produk yang memiliki tampilan menarik akan berfungsi lebih baik (Norman, 2004).

Secara keseluruhan, desain skuter matik di Indonesia dapat memenuhi beberapa karakteristik gender perempuan, yaitu: komunal dengan dapat digunakan oleh seluruh anggota keluarga yang menjadi bagian dari socio-pleasure; kemampuan empati dan kecerdasan emosional dengan desain skuter matik yang menyenangkan, rileks dan santai dan memberikan rasa percaya diri saat digunakan yang merupakan psycho-pleasure. Semakin banyak desain skuter matik dapat memberikan pleasurability yang lebih banyak akan semakin meningkatkan preferensi perempuan pengendara seiring dengan kecenderungan gender perempuan untuk memproses informasi secara komprehensif dan mempertimbangkan seluruh informasi yang tersedia (Meyers-Levy, 1989)

Dari enam bentuk skuter matik yang menjadi stimuli, model skuter matik yang paling memberikan pleasurability bagi perempuan pengendara adalah Motor F atau Honda Scoopy. Persepsi skuter matik dengan bobot yang ringan, terlihat ramping dan gesit, memberikan perasaan bebas dan mudah saat digunakan serta terlihat feminin dan ramah lingkungan yang masuk dalam ideo-pleasure merupakan faktor pleasurability yang terdapat pada persepsi desain motor ini seperti terlihat pada Tabel 2. Dari keseluruhan enam desain skuter matik, hanya Honda Scoopy yang memiliki persepsi "feminin", dimana persepsi ini menjadi penting terkait dengan stereotipe gender perempuan bagi perempuan yang 
memperhatikan pendapat dari lingkungan (Wood \& Eagly, 2012).

Dari hasil pertanyaan terbuka pada kuesioner indepth interview, bagian depan dan lampu depan pada skuter matik merupakan bagian yang menarik bagi perempuan pengendara. Untuk Honda PCX dan Yamaha NMax, bagian jok dan pijakan kaki merupakan bagian khusus yang menarik, sedangkan untuk Honda Scoopy bagian spion, yang memiliki bentuk yang berbeda, menjadi bagian khusus yang menarik bagi perempuan pengendara. Detail bentuk skuter matik menjadi penting bagi perempuan pengendara sesuai dengan karakteristik perempuan yang menghabiskan waktu untuk memperhatikan detail bentuk dari desain produk (Qu \& Guo, 2019) selain itu berdasarkan selectivity hypothesis (MeyersLevy \& Loken, 2015) perempuan melakukan proses informasi secara komprehensif dengan mempertimbangkan subyek dan obyek dari atribut produk dan merespon terhadap isyarat halus atau detail (Darley \& Smith, 1995).

Hasil analisis faktor menunjukkan pembentukan faktor dengan jumlah yang berbeda untuk masingmasing desain skuter matik walaupun aspek pleasurability yang diberikan berjumlah sama. Hal ini menunjukkan persepsi berdasarkan pleasurability dapat dipengaruhi desain skuter matik dengan pembentukan faktor yang berbeda. Semakin banyaknya jumlah faktor yang terbentuk juga dapat dilihat sebagai semakin banyaknya variabel berbeda yang dipersepsi oleh perempuan pengendara dari desain skuter matik tersebut dan karena perempuan juga memiliki pola komprehensif dalam menerima dan memproses informasi dalam pengambilan keputusan (Meyers-Levy \& Loken, 2015), semakin banyak variabel akan mendukung semakin kuatnya persepsi perempuan pengendara terhadap sebuah skuter matik.

Dari pembentukan faktor pleasurability keseluruhan analisis faktor seperti pada Tabel 3, aspek physio-pleasure "berkualitas" sangat berhubungan dengan psycho-pleasure. Aspek sociopleasure "dapat digunakan keluarga" pada Motor A, $\mathrm{B}$ dan $\mathrm{C}$ memiliki korelasi dengan faktor psychopleasure, tetap pada skuter matik dengan ukuran yang lebih besar seperti Motor D dan E, serta karakter bentuk yang berbeda, Motor F lebih memiliki korelasi dengan aspek ideo-pleasure "ekonomis dan murah". Untuk skuter matik ukuran besar, aspek "ekonomis dan murah" juga ternyata berkorelasi dengan aspek "feminin". Untuk skuter matik ukuran kecil seperti Motor A dan B, persepsi physio-pleasure "nyaman" memiliki korelasi kuat dengan bobot yang "ringan" serta tampilan yang "ramping dan gesit". Untuk model skuter matik lainnya, "nyaman" lebih berkorelasi dengan faktor psycho-pleasure.

Dari hasil perceptual matrix berdasarkan 2 (dua) faktor yang terbentuk dengan persentase varian terbesar pada Gambar 1, dapat dilihat secara keseluruhan sebaran yang dominan terdapat pada kuadran II dimana kedua faktor pleasurability tersebut sama-sama memiliki pengaruh yang kuat dalam persepsi pengendara perempuan terhadap masing-masing model skuter matik. Hal ini juga sejalan dengan karakteristik gender perempuan yang lebih komprehensif sesuai dengan teori selectivity hypothesis.

Tabel 3. Pembentukan faktor pleasurability

\begin{tabular}{|c|c|c|c|c|}
\hline Model & Faktor 1 & Faktor 2 & Faktor 3 & Faktor 4 \\
\hline $\mathrm{A}$ & $\begin{array}{l}(1)(5)(9) \\
(10)(11)(12)\end{array}$ & $(6)(7)(8)$ & $(2)(3)(4)$ & $\begin{array}{l}(13)(14)(15) \\
(16)\end{array}$ \\
\hline B & $\begin{array}{l}(1)(2)(3) \\
(4)(5)(9) \\
(10)(12) \\
(13)(15) \\
(16)\end{array}$ & $\begin{array}{l}(6)(7)(8) \\
(11)(14)\end{array}$ & & \\
\hline $\mathrm{C}$ & $\begin{array}{l}(1)(2)(5) \\
(9)(10) \\
(11)(12) \\
(14)(15)\end{array}$ & $\begin{array}{l}(3)(4)(13) \\
(16)\end{array}$ & $(6)(7)(8)$ & \\
\hline $\mathrm{D}$ & $\begin{array}{l}(1)(2)(9) \\
(10)(11) \\
(12)(14) \\
(15)\end{array}$ & $\begin{array}{l}(3)(4)(5) \\
(13)(16)\end{array}$ & $(6)(7)(8)$ & \\
\hline$E$ & $\begin{array}{l}(1)(2)(9) \\
(10)(11) \\
(12)(14) \\
(15)\end{array}$ & $\begin{array}{l}(3)(4)(5) \\
(13)(16)\end{array}$ & $(6)(7)(8)$ & \\
\hline $\mathrm{F}$ & $\begin{array}{l}(1)(2)(3) \\
(4)(9)(10) \\
(11)(12)\end{array}$ & $(6))(7)(8)$ & $\begin{array}{l}(13)(14) \\
(15)\end{array}$ & (5) (16) \\
\hline
\end{tabular}

Faktor pleasurability : (1) Berkualitas, (2) Nyaman, (3) Ringan, (4) Ramping/Gesit, (5) Digunakan keluarga, (6) Terkait status, (7) Berbeda/Menonjol, (8) Diterima lingkungan, (9) Menyenangkan, (10) Relaks \& Santai, (11) Percaya diri, (12) Bebas \& Mudah,

(13) Feminin, (14) Kemandirian, (15) Ramah lingkungan, (16) Ekonomis \& Murah 

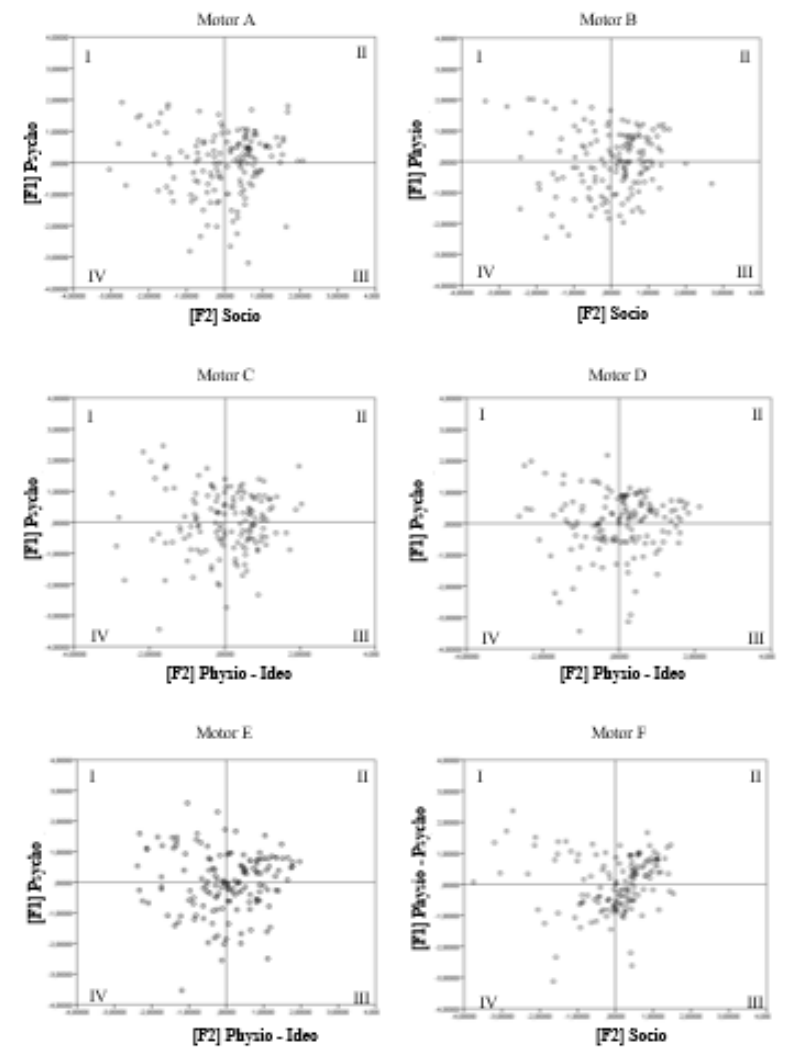

Tabel 4. Analisis faktor dari model skuter matik

\begin{tabular}{ccccccc}
\hline Pleasurability & \multicolumn{6}{c}{ Motor } \\
& A & B & C & D & E & F \\
\hline Psycho & F1 & & F1 & F1 & F1 & F1 \\
Socio & F2 & F2 & & & & F2 \\
Physio & & F1 & F2 & F2 & F2 & F1 \\
Ideo & & & F2 & F2 & F2 & \\
\hline
\end{tabular}

Selain sebaran yang dominan terdapat pada kuadran II, dari Faktor 2 (F2) yang terdapat pada keseluruhan perceptual matrix didapatkan 2 (dua) kelompok model skuter matik, sedangkan pengelompokan berdasarkan F1 dari analisis faktor masing-masing model skuter matik juga mengelompokan desain skuter matik menjadi tiga kelompok seperti terlihat pada Tabel 4. Pemetaan berdasarkan faktor dengan pemuatan terbesar (F1 dan F2) memberikan gambaran pengelompokan desain skuter matik berdasarkan persepsi dari perempuan pengendara seperti yang terlihat pada Gambar 2.

Motor D (Honda PCX) dan E (Yamaha NMax) berada pada posisi kuadran yang sama, dengan ukuran yang sama-sama besar, memiliki bagian menarik yang sama yaitu jok dan pijakan kaki, serta keduanya memiliki persepsi yang serupa walaupun memiliki karakter bentuk yang berbeda. Motor F (Honda Scoopy) menempati posisi pada kuadran tersendiri

Gambar 1. Grafik perceptual matrix model skuter matik

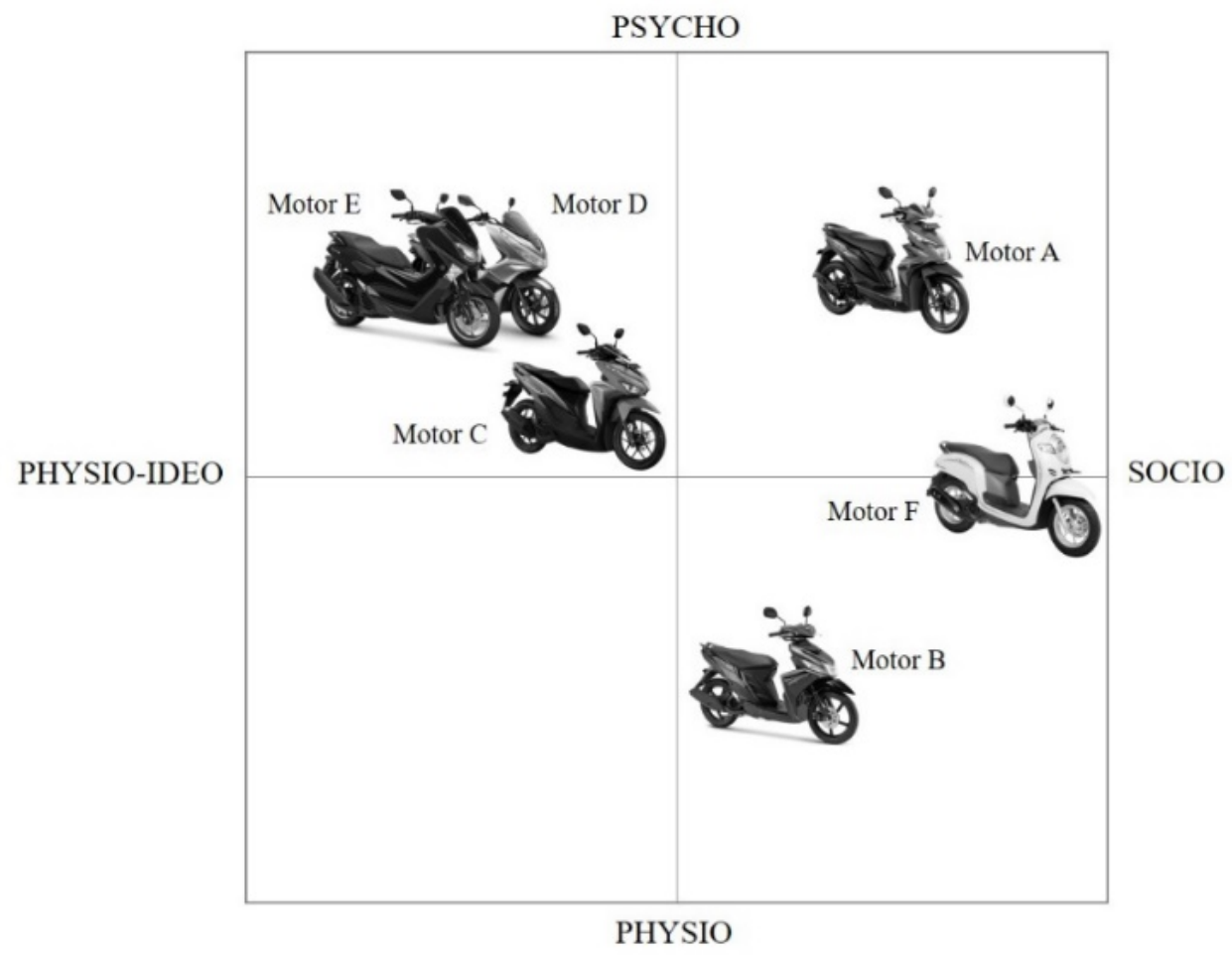

Gambar 2. Pemetaan desain skuter matik berdasarkan analisis faktor 
dimana terdapat persepsi faktor socio-pleasure serta psycho dan physio-pleasure, dengan karakter bentuk desain skuter matik yang berbeda dibandingkan skuter matik lainnya; tidak hanya keseluruhan bentuk secara garis besar tapi pada bagian-bagian yang lebih kecil, seperti bagian spion yang menjadi bagian yang menarik memberikan persepsi faktor pleasurability yang lebih besar. Untuk Motor A (Honda BeAT) dengan ukurannya yang kecil, serta karakter bentuk dan tipe serupa dengan Motor B (Yamaha Mio) menempati area kuadran yang berbeda dengan persepsi pleasurability yang tidak sama. Hal ini semakin memperkuat bahwa selain ukuran sepeda motor, tipe, dan karakter bentuk dari skuter matik, desain baik secara keseluruhan maupun bagian-bagian dari skuter matik memberikan pengaruh pada persepsi berdasarkan pleasurability oleh perempuan pengendara.

\section{Kesimpulan}

Berdasarkan hasil penelitian, desain skuter matik memiliki persepsi sesuai dengan karakteristik gender perempuan yaitu komunal dan memiliki nilai empati atau emosional yang tinggi. Namun demikian, baru memberikan persepsi tiga faktor pleasurability dan belum mencapai tingkat reflektif. Dengan mempertimbangkan karakteristik gender perempuan, pemenuhan persepsi faktor pleasurability yang signifikan pada perkembangan desain skuter matik di masa mendatang dapat meningkatkan persepsi perempuan pengendara terhadap desain skuter matik di Indonesia serta memperkuat interaksi antara produk dan penggunanya. Faktor pleasurability memiliki persepsi yang berbeda-beda untuk setiap bentuk desain skuter matik. Ukuran, tipe, dan karakter bentuk serta detail bagian-bagian dari sebuah skuter matik merupakan hal yang akan mempengaruhi persepsi perempuan pengendara dan mungkin saja memberikan persepsi pleasurability yang berbeda dari perempuan pengendara.

Pemahaman terhadap perbedaan persepsi terkait pleasurability terhadap masing-masing bentuk desain skuter matik ini dapat digunakan dalam mengkomunikasikan sebuah desain skuter matik kepada perempuan pengendara agar materi komunikasi menjadi relevan sesuai dengan persepsi yang mereka miliki dan mampu menarik minat perempuan pengendara. Selain itu dengan memahami karakteristik gender serta persepsi perempuan pengendara terhadap desain skuter matik dapat memberikan wawasan dalam pengembangan desain skuter matik di masa mendatang.

\section{Daftar pustaka}

Asosiasi Industri Sepeda Motor Indonesia. (2019). Data pasar sepeda motor tahun 2000-2018 dan persentase kontribusi tipe skuter matik. Retrieved from Asosiasi Industri Sepeda Motor Indonesia: https://www.aisi.or.id/statistic/

Badan Pusat Statistik. (2018a). Data perkembangan jumlah kendaraan bermotor menurut jenis 1949-2018. Retrieved from Badan Pusat Statistik: https://www.bps.go.id/linkTableDinamis /view/id/1133

Badan Pusat Statistik. (2018b). Data proyeksi penduduk Indonesia 2015-2045. Jakarta: Badan Pusat Statistik.

Baron-Cohen, S. (2003). The essential difference: men, women and the extreme male brain. New York: Penguin/Basic Books.

Darley, W. K., \& Smith, R. E. (1995). Gender differences in information processing strategies: an empirical test of the selectivity model in advertising response. Journal Advertising, 24(1), 41-56.

Hampson, E., van Anders, S. M., \& Mullin, L. I. (2006). A female advantage in the recognition of emotional facial expressions: Test of an evolutionary hypothesis. Evolution and Human Behaviour, 27(6), 401-416.

Jordan, P. W. (2000). Designing pleasurable products: an introduction to the new human factors. London: Taylor \& Francis.

Lippa, R. A. (2010). Gender differences in personality and interest: when, where, and why? Social and Personality Psychology Compass, 4(11), 1098-1110.

Macdonald, A. S. (1999). Aesthetic intellegence: a cultural tool. In Contemporary Ergonomics (pp. 95-99). London: Taylor \& Francis.

Massar, K., \& Buunk, A. P. (2013). Gender differences in adolescent advertising response: The role of involvement and message claim. Psychology, 4(07), 547-552.

Meyers-Levy, J. (1989). Gender differences in information processing: A selectivity interpretation. Lanham: Lexington Books.

Meyers-Levy, J., \& Loken, B. (2015). Revisiting gender differences: What we know and what lies ahead. Journal of Consumer Psychology, 25(1), 129-149.

Mitchell, V. W., \& Walsh, G. (2004). Gender differences in German consumer decision-making styles. Journal Consumer Behaviour, 3(4), 331-346.

Norman, D. A. (2004). Emotional design: why we love (or hate) everyday things. New York: Basic Book.

Popcorn, F., \& Marigold, L. (2008). EVEolution: The Eight Truths of Marketing to Women. New York: Hyperion.

PT Astra Honda Motor. (2018). Project Bike 2018. Jakarta: PT Astra Honda Motor.

Qu, Q.-X., \& Guo, F. (2019). Can eye movements be effectively measured to asses product design?: Gender differences should be considered. International Journal of Industrial Ergonomics, 72, 281-289.

Silverman, I. W. (2003). Gender differences in delay of gratification: a meta-analysis. Sex Roles, 49(9), 451-463.

Szalma, J. L. (2009). Individual differences: Incorporating human variation into human factors/ergonomics research and practice. Theory Issues in Ergonomics Science, 10(5), 377-379.

Vanston, J. E., \& Strother, L. (2017). Sex differences in the human visual system. Journal of Neuroscience Research, 95(1-2), 617-625.

Wood, W., \& Eagly, A. H. (2012). Biosocial construction of sex differences and similarities in behavior. Cambridge: Academic Press. 
Productum Vol 4 No 1 Januari-Juni 2021 pp. 67-76

Yang, C., \& Chen, C.-S. (2014). An investigation on the gender differences of Taiwanese youths and middle ages in evaluation motorcycle appearance dan use. in KEER2014 Proceeding of the 5th International Conference on Kansei Engineering and
Emotion Research. 100, pp. 405-422. Linköping: Japan Society of Kansei Engineering.

$* * *$ 